\title{
A guideline for development a short-term classical guitar curriculum in Thailand
}

\author{
Natthawat Khositditsayanan ${ }^{1}$, Chaloemchai Sosutha ${ }^{2} \&$ Kanit Promnil ${ }^{3}$ \\ ${ }^{1,3}$ Department of Music Education, Faculty of Education, Buriram Rajabhat University, Thailand \\ ${ }^{2}$ Department of Curriculum and Instruction, Fuaculty of Education, Buriram Rajabhat Unversity, Thailand
}

\begin{tabular}{ll}
\hline \hline Article Info \\
\hline Article history: \\
Received & September 21, 2021 \\
Revised & December 2, 2021 \\
Accepted & December 15, 2021
\end{tabular}

Keywords:

classical guitar

curriculum development

short-term curriculum

\begin{abstract}
The objectives of this research were to (1) study criteria for practice of the classical guitar test to be used as a guideline for the entrance examination for higher education in Thailand and (2) find the ways to develop curriculum of a short- term classical guitar for entrance examinations of higher education by studying the information from documents, principles, theories, and criteria of the classical guitar test to be used as a guideline for admission to higher education in Thailand. The results of the research were as follows 1) criteria for practice of classical guitar test to be used as a guideline for the entrance examination for higher education. There were 2 parts of the contents for examination including technically, candidates must be able to practice the scale, length was not more than 4 sharps, 4 flats in major and minor scales with arpeggio and the piece contained and exercise song and 2 general pieces, difficulty from Intermediate to advanced and there were differences in style of music eras or musical styles from different composers and all the pieces that test takers must play from memory, and 2) curriculum of a short-term classical guitar for tertiary entrance examinations that had a content consists of 2 parts. The first one, the content and course details, were the curriculum competency, course descriptions, tools, materials, equipment, training materials and learning resources and background knowledge and qualifications of trainees and the second one, measurement and evaluation consisted of 3 parts : a posttest to review the process and the duration of attending the training was not less than 80 percentage of the training time according to the curriculum.
\end{abstract}

This is an open access article under the CC BY-SA license.

\author{
Corresponding Author: \\ Chaloemchai Sosutha \\ Departrment of Curriculum and Instruction \\ Faculty of Education \\ Burirm Rajabhat University \\ Thailand \\ Email: tom431051039@yahoo.co.th
}

\section{INTRODUCTION}

The current word is evolving rapidly according to economic capitalism that affected both sides of society. Education is one that is influenced by socio-economic trends clearly (Quality learning foundation, 2014). In terms of music education, there is a cost of both equipment preparation and tuition fees were quite high in music colleges or large universities. These problems affect in music teaching which is limited in the Bangkok area. Essentially, music teaching is an additional study outside of school classes as it is a specialized science. It is not taught at the level of schools but also general education institutions so musical students have high educational expenses, including the cost of preparing for further examinations and The cost of preparing or basic adjustment in order to both pass standardized examinations and have knowledge and readiness for higher education.

For music teaching, instructors must understand learner's learning process and are able to arrange music lessons to be more suitable for students. In psychology, learning theory can be divided into four groups are behaviorism, cognitivism, humanism and social learning theory (Merriam \& Caffarella, 1999). There are many ways to teach, teaching at present will focuses on teaching that can develop students with all knowledge, skills and 
attitudes by using teaching and learning activities that focus on students, teaching techniques are used different tactics to enhance the process and teaching methods are used in teaching to help students learn. Each method has its own unique components and procedures leading to its specific purpose (Khammani, 2018). Music measurement and evaluation are an essential part of the process of music education, especially in learning management. There are generally two types of assessments : formative assessment and summative assessment. In music, these two aspects of evaluation always occur in teaching music, especially learning skills. (Suttachitt, 2012).

Curriculum development of a short-term music practice to prepare for higher education, it is one way to help students in the high school level who are interested in studying music in higher education to learn music in order to prepare to build a body of knowledge that is important for higher music learning which practical music,theorical music and audiovisual education. This requires someone who has the knowledge and expertise to convey the basic knowledge of music to be accurate (Sayawongs \& Pum-in, 2017). The curriculum development of short-term music practice has also contributed to the distribution of music knowledge that is the same standard with leading music institutions and reduce disparities in music education for local youths in Buriram Province and cost to prepare exams for higher education. It also mncourage youths to have benefit activities outside school and can develop expertise until they become a career that can generate income in the future. Moreover; it can develop education for the locality to achieve sustainable development of youths, schools, and educational institutions as a basis for promoting other music activities to enhance the quality of life through art and music for Buriram City (Khositditsayanan, 2016).

\section{METHOD}

2.1 Studying documents, principles, theories and criteria of practice of classical guitar tests to be used as a guideline for entrance examinations for higher education in Thailand.

\subsubsection{Oparation}

2.1.1.1 To study concepts and theories about criteria to be used as criteria for practice of classical guitar tests as a guideline for entrance examinations for higher education with specifying the issue of study documents.

2. 1.1.2 To draft the issue of study documents.

2.1.1.3 To bring the draft of the issue of the study document presented to the experts to consider and check the accordance with the objectives and appropriateness for improvement.

2. 1.1.4 To plan the study and analyze documents.

2. 1.1.5 To record data and analyze data.

2. 1.2 Tools and quality of tools

To synthesize document by using the record of document synthesis form created by the researcher. It had been inspected by 5 experts, checking the quality to be appropriate.

2. 1.3 Data analysis

To use content analysis methods to obtain an inductive conclusion, the final goal was basic information about the actual conditions for criteria of practice of the classical guitar test to be used as a guideline for the entrance examinations to higher education.

2.2 Studying documents, principles, theories and guidelines for curriculum development of a short-term classical guitar for tertiary entrance examinations.

\section{2.1Operation}

2. 2.1.1 To study of concepts and theories on guidelines for curriculum development a shortterm classical guitar for entrance examinations of higher education with specifying the issue of study documents.

2. 2.1.2 To draft the issue of study documents.

2. 2.1.3 To bring the draft of the issue of the study document presented to the experts to consider and check the accordance with the objectives and appropriateness for improvement.

2. 2.1.4 To plan the study and analyze documents.

2. 2.1.5 To record data and analyze data.

2. 2.2 Tools and quality of tools

To synthesize document by using the record of document synthesis form created by the researcher. It had been inspected by 5 experts, checking the quality to be appropriate.

2.2.3 Data analysis

To use content analysis methods to obtain an inductive conclusion, the final goal was basic information about the actual conditions for guidelines for curriculum development a short-term classical guitar for entrance examinations of higher education. 


\section{RESULT}

3.1 The criteria for practice of the classical guitar test to be used as a guideline for the entrance examination for higher education in Thailand

The criteria for practice of the classical guitar test to be used as a guideline for the entrance examination for higher education that had 2 parts of the exam contents :

3.1.1 Techniques, the candidates could practice the basic sound scale such as the scale, the difficulty was not more than 4 sharps, 4 flats, both the major scale, harmonic minor stairs and the melodic minor scale. In addition, an arpeggios must be played with a difficulty of no more than 4 sharps, 4 flats on the major and minor scales.

3.1.2 In terms of pieces, it consisted of exercise songs and general pieces or independent pieces. The exercises were selected from songs by various composers, for example 20 Studies by Fernando Sor, 12 Etudes by Hector Villa Lobos, 25 Studies Op.6 0 by Matteo Carcassi and 20 Etudies by Leo Brouwer. A general or independent piece consisted of 2 different pieces, ranging in difficulty from intermediate to advanced levels and there were differences in style, music eras or styles of music from composers such as Bach, Brouwer, Weiss, Sor, Giuliani, etc. and all pieces must be played from memory.

3.2 Curriculum of a short-term classical guitar for entrance examinations of higher education

From studying the criteria for practice of classical guitar test to be used as a guideline for the entrance examination for higher education, researcher had adopted a guideline for curriculum of a short-term classical guitar for the entrance examinations for higher education which the content consisted of

\subsubsection{Contents and details of curriculum}

3.2.1.1 Curriculum competency

1) To show general knowledge about classical guitar.

2) To performs classical guitar techniques, including sound scale and arpeggio, both major and minor, length 4 sharps, 4 flats.

3) To play classical guitar according to the given pieces, including exercises and general pieces.

\subsubsection{Curriculum description}

To study and practice on classical guitar, play classical guitar techniques such as scale and arpeggio and play classical guitar pieces in accordance with the specified pieces such as exercise pieces and general pieces. A Course duration had 36 hours

Table 1 Contents for curriculum of a short-term classical guitar for the entrance examination for higher education

\begin{tabular}{|c|c|c|c|}
\hline Unit plan & Training topics & $\begin{array}{c}\text { Time of studying } \\
\text { (12 Times) }\end{array}$ & $\begin{array}{c}\text { Number of hours } \\
\text { (36 Hours) }\end{array}$ \\
\hline 1 & $\begin{array}{l}\text { General knowledge about classical guitar : Content } \\
\text { includes } \\
1.1 \text { History of the classical guitar } \\
1.2 \text { Guitar parts and maintenance } \\
\text { 1.3 Characteristics of playing classical guitar } \\
\text { 1.4 Classical Guitar Pieces } \\
\text { 1.5 Techniques for playing classical guitar } \\
\end{array}$ & 1 & 3 \\
\hline 2 & $\begin{array}{l}\text { Performing classical guitar techniques, including } \\
\text { scale and apeggio both major and minor length for } \\
4 \text { sharps and flats (Scale and arpeggio length for } 2 \\
\text { Octave) Content consists of } \\
\text { Major scale: } \\
\text { 2.1 C Major } \\
\text { 2.2 G Major } \\
\text { 2.3 D Major } \\
\text { 2.4 A Major } \\
\text { 2.5 E Major } \\
\text { 2.6 F Major } \\
\text { 2.7 B Major } \\
\text { 2.8 Eb Major } \\
\text { 2.9 Ab Major } \\
\text { Minor scale: } \\
\text { 2.10 A Minor } \\
\text { 2.11 E Minor }\end{array}$ & $2-3$ & 6 \\
\hline
\end{tabular}




\begin{tabular}{|c|c|c|c|}
\hline Unit plan & Training topics & $\begin{array}{l}\text { Time of studying } \\
\text { (12 Times) }\end{array}$ & $\begin{array}{c}\text { Number of hours } \\
\text { (36 Hours) }\end{array}$ \\
\hline & $\begin{array}{l}\text { 2.12 B Minor } \\
\text { 2.13 F\# Minor } \\
2.14 \text { C\# Minor } \\
\text { 2.15 D Minor } \\
2.16 \text { G Minor } \\
\text { 2.17 C Minor } \\
\text { 2.18 F Minor } \\
\text { Note: The minor scale should be played in } \\
\text { harmonic minor and melodic Minor. }\end{array}$ & & \\
\hline 3 & $\begin{array}{l}\text { Playing a piece, type of exercise, choose } 2 \text { pieces } \\
\text { from the list of pieces given. } \\
\text { 3.1 Etudes No. 1by D. Aguado } \\
\text { 3.2 Etudes No. } 2 \text { by D. Aguado } \\
\text { 3.3 Etudes Op. } 60 \text { No. } 2 \text { by M. Carcassi } \\
\text { 3.4 Etudes Op. } 60 \text { No. } 3 \text { by M. Carcassi } \\
\text { 3.5 Etudes No. } 12 \text { by F. Tarrega } \\
\text { 3.6 Etudes No. } 18 \text { by F. Tarrega } \\
\text { 3.7 Etudes No. } 1 \text { by H. Villa-Lobos } \\
\text { 3.8 Etudes No. } 6 \text { by H. Villa-Lobos } \\
\text { 3.9 Simple Etude No.6 by Leo Brouwer } \\
\text { 3.10 Simple Etude No.15 by Leo Brouwer }\end{array}$ & $4-6$ & 9 \\
\hline 4 & $\begin{array}{l}\text { Playing a piece, general type of piece, choose } 3 \\
\text { pieces from the list of pieces given. } \\
\text { 4.1 Minuet in A by F. Sor } \\
\text { 4.2 Minuet from Sonatina } 1 \text { Op. } 71 \text { by M. } \\
\text { Giuliani } \\
\text { 4.3 El Testament d'Amelia by M. Llobet } \\
\text { 4.4 El Noi De La Mare by M. Llobet } \\
\text { 4.5 Julia Florida by A. Barrios } \\
\text { 4.6 Villancico de Navidad by A. Barrios } \\
\text { 4.7 Vals in D by F. Tarrega } \\
\text { 4.8 Tango by F. Tarrega } \\
\text { 4.9 Vals Venezolano No.1 and } 2 \text { by A. Lauro } \\
\text { 4.10 Cavatina by S. Myers } \\
\text { Note: Choosing pieces that are different in music } \\
\text { era or music style. }\end{array}$ & $7-12$ & 18 \\
\hline
\end{tabular}

Note : Studying 12 times (3 hours a time) and 4 weeks ( 3 times a week)

3.2.1.3 Tools, materials and equipments

(1) Classical guitar with stand and bag

(2) Foot stool

(3) Note stand

(4) Stool

(5) Five line board

(6) Projector with a screen

(7) Musical computer

(8) Air-conditioned classroom, 3 walls and ceiling are lined with soundproofing material, one wall is a mirror and the door has a clear glass window to see inside the room

3.2.1.4 Training document and learning resources

1) Khositditsayanan, N. (2016). Practice of classical guitar 1. Buriram: Buriram Rajabhat University Press.

2) Pancharoen, N. (2008). Musical theories. $8^{\text {th }}$ ed. Bangkok: Ketkarat Press.

3.2.1.5 Basic knowledge and qualifications of trainees

The trainnes must have basic knowledge of classical guitar and be able to read and write international notes. 
3.2.2 Measurement and evaluation consists of 3 parts:

3.2.2.1 A music knowledge test is a post-test.

3.2.2.2 A practice assessment form is use for check practice process.

3.2.2.3 The duration of participation in the training is not less than $80 \%$ of the training time according to the curriculum. The assessment tool is a training attendance recording form.

Table 2 Measurement and evaluation for curriculum of a short-term classical guitar

\begin{tabular}{|c|l|l|c|}
\hline Number & \multicolumn{1}{|c|}{ Assessment guidelines } & \multicolumn{1}{c|}{ Assessment tool } & Assessment criteria \\
\hline 1 & To test after training & A music knowledge test & 20 \\
\hline 2 & To check practice process & A practice assessment form & 80 \\
\hline 3 & $\begin{array}{l}\text { The duration of participation in the } \\
\text { training is not less than 80\% of the } \\
\text { training time according to the } \\
\text { curriculum. }\end{array}$ & $\begin{array}{l}\text { A training attendance record } \\
\text { form }\end{array}$ & - \\
\hline \multicolumn{2}{|c|}{ Total score } & 100 \\
\hline
\end{tabular}

\section{DISCUSSION}

4.1 The criteria for practice of the classical guitar test to be used as a guideline for the entrance examination for higher education consists of two parts:

4.1.1 Techniques, the candidates are able to practice the basic sound level that consiste of a scale and apeggio, both major and minor, length 4 sharps and flats. These accord with Sayawongs \& Pum-in (2017) said that the concept of teaching both the major and minor scales is important for learning music. Because the scale is the order of every note in a given key. It sets a system for composing music and sets a method for practicing basic music that cannot be ignored. Therefore, learners need to have knowledge of the structure of all major scales and different types of minor, including natural minor, harmonic minor and melodic minor, be able to understand the scale marking which specified in each piece correctly. They are able to sequence different notes, all types of scales. However, learners has a good knowledge of music theory about scales but practice may be more difficult for beginning. Therefore, learners are encouraged to start with finger exercises that will help them to develop the relative readiness of the fingers, increase dexterity and strength of fingers and wrists on classical guitar.

4.1.2 Pieces, they consist of exercise songs and general piece or independent pieces, contains 2 different pieces, ranging in difficulty from intermediate to advanced levels and there are differences of all music eras or styles and pieces must be played from memory. These accord with Inthaniwet (2020) said that teaching classical guitar in higher education can use pieces in learning management which should be divided into 2 types is 1) a group of pieces that are exercise pieces in the style of music of different eras and pieces that focus on technical skills to be appropriate to their learning level and 2) a group of pieces that are used for performances, should be independently chosen pieces according to the interests of each learner but should be at the discretion on instructors and according to Khositditsayanan (2018) said that the pieces are used in the classical guitar curriculum of Thai music colleges are divided into two groups are 1) exercise pieces, the objective of the piece is to practice learners'skills in playing classical guitar, both the development for left-handed techniques and the development of right-handed techniques. Most of the pieces used are composed by composers such as Fernando Sor, Matteo Carcassi, Leo Brouwer, Hector Villa-Lobos, Mauro Giuliani and Giulio Regondi, etc. Instructors will choose what pieces should be learned for learners, it depends on the learners' skill level and the objective of the piece that they want to use to improve which skills of learners are still lacking and 2) Repertoires, objective of these are to make students can understand the pieces of different eras, analyze and convey the mood of the pieces correctly. Therefore, contents in classical guitar teaching is imperative learners who learn a variety of pieces. Most of the songs used are composed by major composers such as Agustín Barrios Mangoré, Roland Dyens, Manuel de Falla, Antonio Lauro, Federico Moreno Torroba, Joaquín Rodrigo, Andrés Segovia, Fernando Sor, Francisco Tárrega and Heitor Villa-. Lobos, etc., learners must have knowledge and be able to perform various pieces in a variety of styles and in accordance with the style of each era.

4.2 This curriculum of a short-term classical guitar for the entrance examination for higher education has 2 parts : 1) contents and detail with curriculum competency, curriculm description, tools, materials, equipments, training ducuments and learning resources. and basic knowledge and qualifications of trainees and 2) measurement and evaluation consist of 3 parts : test after training, check practice process and the duration of participation in the training is not less than $80 \%$ of the training time according to the curriculum. This accord with Nuangchalerm (2011) said that curriculum components of all level have 3 basic components consist of aims, contents and allocating time for various teaching activities. The details are as follows : 1) The aims of the curriculum must be appropriate to the nature of the learners 2) the content scope of the curriculum is determined by the aims of the curriculum and 3) allocating time for various teaching and learning activities in order to carry out teaching activities in accordance with the aims of the curriculum. 


\section{CONCLUSION}

The criteria for practice of classical guitar test to be used as a guideline for the entrance examination for higher education. There were 2 parts of the contents for examination including technically, candidates must be able to practice the scale, length was not more than 4 sharps, 4 flats in major and minor scales with arpeggio and the piece contained and exercise song and 2 general pieces, difficulty from Intermediate to advanced and there were differences in style of music eras or musical styles from different composers and all the pieces that test takers must play from memory.

Curriculum of a short-term classical guitar for tertiary entrance examinations that had a content consists of 2 parts. The first one, the content and course details, were the curriculum competency, course descriptions, tools, materials, equipment, training materials and learning resources and background knowledge and qualifications of trainees and the second one, measurement and evaluation consisted of 3 parts : a post-test to review the process and the duration of attending the training was not less than 80 percentage of the training time according to the curriculum.

\section{ACKNOWLEDGEMENT}

This research cloud be successful because cooperation from all researcher team who joined together in the research and fixed any mistiakes with carefulness. Special thanks for Faculty of Education, Buriram Rajabhat University that donated scholarships for this research and all the experts who gave advice to improve and develop research to be complete.

In addition, the research team hoped this research will be of some benefit. Therefore, I would like to give a good portion to all researchers for various defected that may occur. The research team accepted liability and was willing to listen to advice from everyone who has come to study to be useful in further research development.

\section{REFERENCES}

Inthaniwet, O. (2020). Evolution of the classical guitar and guidelines for teaching classical guitar practice the higher education. Journal of Fine Arts Research and Applied Arts. 7(1), 107-121.

Khammani, T. (2018). Science of teaching: Body of knowledge for effective management of learning process. $18^{\text {th }}$ ed. Bangkok: Darnsutha Press. (in Thai)

Khositditsayanan, N. (2016). Classical guitar practice 1. Buriram: Buriram Rajabhat University Press. (in Thai)

Khositditsayanan, N.. (2018). Classical guitar pedagogy for college of music in Thailand. Doctoral thesis, Mahasarakham University. (in Thai)

Merriam, S. \& Caffarella, R. (1999). Learning in adulthood: A comprehensive guide. $2^{\text {nd }}$ ed. San Francisco: Jossey Bass.

Nuangchalerm, P. (2011). Educational curriculum. Mahasarakham: Apichart Prining. (in Thai)

Pancharoen, N. (2008). Musical theories. $8^{\text {th }}$ ed. Bangkok: Ketkarat Press. (in Thai)

Quality learning foundation. (2014). Prosperity of learning to the turning point of Thailand: Documents for academic conferences. Bangkok: Quality Learning Foundation.

Sayawongs, S. \& Pum-in, P. (2017). Analysis of music content for selection of classical guitar practice songs at the higher education level. National Conference : Academic Arts 2 : Arts 4.0 : Arts for Creativity and Arts for Education (1-16). Bangkok: Srinakharinwirot University. (in Thai)

Suttachitt, N. (2012). Music education principles and essence. $9^{\text {th }}$ ed. Bangkok: Chulalongkorn University Printing House. (in Thai) 